\title{
Dampak Perkawinan Adat Antar Etnis Mandailing dengan Etnis Minangkabau Terhadap Kekerabatan dan Hak Waris Anak di Kabupaten Pasaman
}

\author{
Aguswita Wahyuni, Nurman S \\ Program Studi Pendidikan Pancasila dan Kewarganegaraan \\ Universitas Negeri Padang \\ E-mail: Aguswithawahyuni@gmail.com
}

\section{ABSTRAK}

Tujuan artikel ini untuk mengungkapkan bagaimana dampak perkawinan adat antar etnis Mandailing dengan Etnis Minangkabau terhadap sistem kekerabatan dan hak waris di Nagari Lansek Kadok Kecamatan Rao Selatan Kabupaten Pasaman. Informan penelitian ini adalah Wali Nagari Rao Selatan, Pengurus KAN, tokoh adat Mandailing dengan Minangkabau dan Masayarakat yang melakukan perkawinan antar etnis adat serta masyarakat yang tidak melakukan perkawinan antar etnis adat. Data ini di diperoleh melalui observasi, wawancara, dan studi dokumentasi. Hasil penelitian ini menunjukkan bahwa perkawinan adat antar etnis Mandailing dengan etnis Minangkabau mempunyai dampak terhadap sistem kekerabatan dan hak waris anak. Dampaknya adalah sistem kekerabatan anak di akui baik dikeluarga ayah dan ibu tetapi ketika anak dewasa mereka lebih dekat dengan kekerabatan ibunya. Dari hasil pernikahan suami etnis Minangkabau dengan istri etnis Mandailing adalah anak-anak tidak dekat dengan kekerabatan ayah dan ibunya sehingga ketika dewasa, dia mencari keluarga angkat baik dari pihak ayah maupun ibunya. Dari aspek pembagian hak waris suami etnis Mandailing dengan istri etnis Minangkabau, dampaknya adalah anak laki-laki dengan anak perempuan sama-sama sebagai ahli waris dari orang tuanya dan memperebutkan hak waris orang tuanya. Jika suami dari etnis Minangkabau dengan istri etnis Mandailing dampaknya adalah hak waris orang tua tidak bisa diturunkan kepada anak sehingga keluarga ini tidak lagi memakai hukum waris adat tetapi memakai hukum waris menurut ajaran agama islam.

Kata Kunci: perkawinan antar etnis, sistem kekerabatan, hak waris

\section{ABSTRACT}

The purpose of this article is to reveal how the impact of intermarriage between Mandailing and Minangkabau on the kinship system and inheritance rights in Nagari Lansek Kadok, South Rao District, Pasaman Regency. The informants of this research are Wali Nagari Rao Selatan, KAN Management, Mandailing traditional leaders with Minangkabau and the people who do inter-ethnic marriages and people who don't inter-ethnic marriages. This data was obtained through observation, interviews, and documentation studies. The results of this study indicate that the intermarriage between Mandailing and Minangkabau ethnic groups has an impact on the kinship system and children's inheritance rights. The 
impact of the kinship system of the Mandailing ethnic husband and the Minangkabau ethnic wife is that the impact on the kinship system of the child is recognized in both the father and mother family but when the child is closer to the father's kinship than the mother after their adult children are closer to the mother's kinship. If the husband from Minangkabau and wife from Mandailing, the impact is that children are not close to the kinship of his father and mother, when his adult children look for foster families on both his father and mother's side. The impact of the inheritance of the Mandailing ethnic husband with the Minangkabau ethnic wife, the impact is that the son and daughter are both the heirs of their parents and fight for the inheritance of their parents. When Minangkabau ethnic as husband with his ethnic Mandailing as wife, the impact is that the inheritance rights of the parents cannot be passed on to the children so that the family no longer uses customary inheritance law but uses inheritance law according to Islam.

Keywords : interethnic marriage, kinship system, inheritance rights

This work is licensed under the Creative Commons Attribution-ShareAlike 4.0 International License. (02019 by author.

\section{PENDAHULUAN}

Perkawinan menurut Hukum Adat yaitu suatu peristiwa yang sangat penting di dalam kehidupan masyarakat adat. Sebab perkawinan tidak hanya menyangkut kedua mempelai saja, tetapi menyangkut orang tua kedua belah pihak, saudarasaudaranya, dan keluarga masingmasing. Dalam Ilmu Sosiologi perkawinan antar etnis mempunyai arti yaitu perkawinan antara dua pihak yang berbeda golongan, agama, suku bangsa, dan kebudayaan (Setiady, 2009:254). Kedudukan anak dalam perkawinan ini juga mempunyai pengaturan yang melatar belakangi pada susunan masyarakat adat bersangkutan dan bentuk perkawinan orang tua yang di pakai atau berlaku. Menurut Yunus (2001) menjelaskan bahwa dalam masyarakat kekerabatan patrilineal, istri masuk dalam kelompok kekerabatan suami dan kedudukan anak akan menggunakan garis keturunan laki-laki atau bapak. Apabila masyarakat yang menggunakan matrilineal cendrung melakukan perkawinan dalam bentuk semenda atau sumando, dimana marapulai atau suami menetap dikediaman kaum kerabat istri, atau di dalam lingkungan kekerabatan istri. Namun, status marapulai atau suami tidak berubah menjadi status istrinya. Status suami dalam lingkungan kekerabatan istrinya adalah dianggap sebagi tamu terhormat, maka kedudukan anak akan menggunakan garis keturunan wanita atau ibu (Amir: 2011). Masyarakat yang menggunakan sistem bilateral atau parental akan menarik garis keturunan melalui garis laki-laki atau bapak maupun perempuan atau ibu, sehingga kelurga seperti ini pada hakikatnya tidak ada perbedaan antara bapak atau ibu.

\section{Selain hukum perkawinan} hukum kewarisan juga merupakan bagian dari hukum keluarga. Waris dapat di artikan segala sesuatu peninggalan tentang kekayaan (bisa asset atau uang) yang ditinggalkan pewaris dan akan dialihkan atau diwasiatkan kepada ahli waris. Bentuk sistem warisan sangat erat kaitannya 
dengan bentuk masyarakat dan sifat kekeluargaan. Sedangkan sistem kekeluargaan masyarakat Indonesia memakali sistem garis keturunan. Indonesia mempunyai tiga macammacam sistem keturunan yang pertama sistem patrilineal/sifat kebapak-an, dimana keturunan anak laki-laki yang akan menjadi pewaris kalau pewaris tidak mempunyai turunan laki-laki, maka harta bendanya diwariskan kepada ahli waris lainnya yang terdiri dari orang laki-laki yang satu marga dan satu keturunan dengan pewaris (Sagiman: 2001). Kedua sistem matrilineal/sifat keibuan, contohnya di Minangkabau yang menganut sistem matrilineal jenis harta pusako terbagi dua yaitu pusako tinggi dengan pusako rendah. Pusako tinggi yaitu harta yang tidak dapat diturunkan kepada anak menurut hukum syarak karena bukan miliknya. Pusako tinggi hanya dapat diturunkan dari ninik ke mamak dari mamak kepada kemenakan. Sedangkan pusaka rendah berasal dari harta pencaharian suami isteri. Pusako rendah dibagi atau diwariskan menurut hukum faraidh (Sayuti:2002). Ketiga sistem bilateral atau parental/sifat kebapak-ibuan dimana sistem ini menggunakan garis orang tua atau menurut garis dua sisi (bapakibu). Didalam sistem pewarisan ini tidak membedakan kedudukan pria dan wanita.

Dikalangan masyarakat masih banyak yang menggunakan kekerabatan adatnya yang lama, dimana kekerabatan yang sama akan berlaku sistem warisan adat yang sama. Namun dengan seiring berkembangnya ilmu pengetahuan, teknologi informasi menyebabkan mobilitas masyarakat yang begitu tinggi tidak lagi mengenal batas wilayah, suku, agama bahkan wilayah negara. Kondisi ini akan memungkinkan terjadinya perkawinan antar etnis antara orang yang berbeda wilayah, agama, suku bahkan kebudayaan antar negara. Apabila perkawinan yang berbeda kekerabatannya maka sistem pewarisannya akan berbeda pula. Berdasarkan pengamatan penulis di Nagari Lansek Kadok ternyata ditemukan adanya perkawinan antara masyarakat yang berbeda sistem kekerabatannya misalnya perkawinan antara masyarakat batak yang memakali sistem kekerbatan patrilineal dengan masyarakar Minangkabau yang menganut sistem kekerabatan matrilineal. Hal itu dapat dilihat pada tabel berikut

Tabel 1.1

Jumlah Keluarga Yang Melakukan Perkawian Campur Di Nagari Lansek Kadok (Dokumen KUA Nagari Lansek Kadok Tahun 2019)

\begin{tabular}{|l|l|c|}
\hline No & \multicolumn{1}{|c|}{ Nama Jorong } & KK \\
\hline 1. & Kotanopan Setia & 11 \\
\hline 2. & Rambahan & 72 \\
\hline 3. & Bringin & 47 \\
\hline 4. & Koto Panjang & 9 \\
\hline 5. & Lansek Kadok & 7 \\
\hline \multicolumn{2}{|c|}{ Total } & 146 \\
\hline
\end{tabular}

Adanya perkawinan berbeda kekerabatan ini membuka peluang terjadinya perselisihan sangketa khususnya dalam kedudukan kekerabatan sistem adat anaknya dan pembagian harta warisan. Terlebih jika salah satu dari pasangan meninggal dunia maka dapat menimbulkan persoalan dibidang hukum waris. Berdasarkan hasil pengamatan dan wawancara, maka terdapat 3 kondisi dan permasalahan yang ditemukan 
Volume 2 No. 52019

dalam keluarga yang melakukan perkawinan campur. Kondisi pertama, suami bernama Yultahri memiliki sistem kekerabatan Minangkabau yaitu matrilineal suku Maek. Sedangkan istri bernama Khodijah berusia 58 tahun memiliki sistem kekerabatan Mandailing yaitu patrilineal marga Nasution dan mempunyai anak empat orang.

Permasalahan yang terjadi dalam rumah tangga dimana sistem kekerabatan yang dimilki suami dan istri tidak bisa digunakan dalam rumah tangga sehingga keturunanya tidak memiliki garis keturunan dalam kekerabatan dan pembagian harta warisan. Sehingga muncul permasalahan dimana terjadi konflik antara anak dengan anak dan anak dengan orang tua untuk mendapatkan harta warisan baik itu anak dari pihak laki-laki dan anak pihak perempuan. Menurut anak laki-laki dia memakai sistem kekerabatan patrilineal dan menurut anak perempuan dia memakai sistem kekerabatan matrilineal sehingga anak perempuan juga berhak untuk mendapatkan harta warisan. Akibat konflik ini anak antara anak terjadi cekcok dan permasalahan sehingga mereka memutuskan tali persaudaraan di akibatkan tidak adanya garis keturunan tersebut.

Permasalahan kedua, suami bernama Asrat berusia 50 tahun memakai sistem kekerabatan mandailing yaitu marga Lubis dan istri bernama Marni berusia 46 tahun memakai sistem kekerabatan Minangkabau yaitu Suku Tanjung. Pasangan ini memiliki anak 6 orang. Permasalahan yang ditemukan pada rumah tangga ini dimana sistem kekerabatan kedua belah pihak bisa digunakan. Dari pihak kelurga suami meminta sistem kekerabatannya dipakai dan dari pihak istri juga meminta demikian sehingga antara kelurga pihak suami dengan kelurga pihak istri terjadi terjadi konflik dan berpengaruh besar terhadap keharmonisan keluarga yang melakukan perkawinan campur. Kondisi ini jika dibiarkan maka dapat mengakibatkan perceraian akibat sistem kekerabatan.

Penelitian yang dilakukan oleh Tagor Raudy "Paraktek Perkawinan Jujur Antara Masyarakat Batak Dengan Masyarakat Minangkabau Di Kecamatan Panti Kabupaten Pasaman" menyimpulkan perkawinan masyarakat Batak dengan masyarakat Minangkabau di Kecamatan Panti pada umumnya berlangsung dengan cara perkawinan jujur. Dimana yang melakukan perkawinan merasa perkawinan jujur memberikan untung terhadap kedua belah pihak dan suami akan bertanggung jawab sepenuhnya terhadap istri dan kelurga. Akibat hukum terhadap anak dalam perkawinan jujur yaitu antara masyarakat Batak dengan masyarakat Minangkabau sangat berpengaruh, karena orang tua yang berasal dari suku Minangkabau akan diangkat menjadi suku Batak sehingga anak dalam perkawinan akan mewarisi marga dari bapaknya.

Penelitian lain yang juga membahas kawin campur yaitu yang dilakukan oleh Riyan Fitriamoko dengan judul "Praktek Perkawinan Campur Antara Masyarakat Adat Dikota Batam Dan Akibatnya (Studi Pada Perkawinan Campur Antara Pria Batak Dengan Wanita Minangkabau Di Sungai Panas Kota Batam). 
Penelitian tersebut menyimpulkan bahwa akibat perkawinan campur antara pria Batak dan wanita Minangkabau menimbulkan berbagai masalah dalam implementasi budaya yang dianut oleh kedua mempelai dalam membina sebuah keluarga baru. Untuk mengatasi permasalahan yang di hadapi, kedua belah pihak mengambil jalan tengah dengan memakai Perundang-undangan Nasional yaitu Undang-Undang Perkawinan Nomor 1 tahun 1974, dalam menghadapi permasalahan kekerabatan, permaslahan keturunan, permaslahan harta benda dan permasalahan warisan.

Penelitian terdahulu juga membahas tentang "Sistem Pewarisan Dalam Perkawinan Antara Suku Batak Dan Suku Minangkabau (Studi Di Kota Medan) yang ditulis oleh Ulfa Sundari tahun (2013). Penelitian tersebut menyimpulkan pembagian warisan dalam perkawinan campur ditinjau melalui Pasal 43 ayat (1) UU No. 1 tahun 1974 menyatakan bahwa: "anak yang dilahirkan diluar perkawinan hanya mempunyai hubungan perdata dengan ibu dan keluarga ibunya. Hubungan dimaksud juga menyangkut dengan hak waris atas harta warisan orang tua yang diatur dalam hukum waris". Penelitian lainnya berjudul "Adat Istiadat Dalam Kelurga Amalgamasi Batak Dan Minangkabau Di Kecamatan Tampan Dan Payung Sekaki Kota Pekanbaru" yang ditulis oleh Sumiati Simanjuntak. Penelitian ini membahas bagaimana penerapan nilai adat istiadat dalam keluarga amalgamasi Batak dan Minangkabau dan dominan budaya dari masing masing suku dalam keluarga amalgamasi Batak dan Minangkabau. Penelitian selanjutnya yang peneliti temukan berjudul "orang Minangkabau dan Batak Mandailing di Nagari Buayan" yang ditulis oleh Adri Febrianto (2011). Penelitian ini membahas pengaruh Minangkabau terhadap proses adaptasi unsur-undur kebudayaan suku bangsa Mandailing ke dalam unsur-unsur kebudayaan suku bangsa Minangkabau yang dominan.

Penelitian yang dilakukan ini berbeda dengan penelitian sebelumnya karena penelitian ini membahas tentang pembagian warisan dari hasil perkawinan antar sistem kekerabatan Mandailing dengan sistem kekerabatan Minangkabau. Pada penelitian sebelumnya belum ditemukan penelitian menyangkut permasalahan tentang pembagian harta warisan dari hasil perkawinan antara sistem kekerabatan Mandailing dengan sistem kekerabatan Minangkabau. Sehingga untuk mengatasi perselisihan atau permasalahan yang di akibatkan perkawinan antar etnis ini masih belum di dapatkan. Penelitian ini fokus pada kekerabatan dan pembagian hak waris yang dihasilkan perkawinan antar adat Mandailing dengan adat Minangkabau dan solusi untuk kekerabatan dan pembagian hak waris dari perkawinan antar etnis tersebut

\section{METODE PENELITIAN}

Penelitian ini menggunakan penelitian kualitatif deskripsi yang bertujuan untuk mendeskripsikan dampak hasil perkawinan adat antar Etnis Mandailing dengan Etnis Minangkabau terhadap kekerabatan dan hak waris anak di Nagari Lansek Kadok Kecamatan Rao Selatan Kabupaten Pasaman. Data diperoleh 
melalui observasi, wawancara, dan studi dokumentasi yang dipilih melalui tehnik purposive sampling yaitu tehnik pemilihan informan yang dianggap lebih mengetahui mengenai penelitian. Informan penelitian ini ialah wali nagari, tokoh adat, pengurus lembaga adat Kerapatan Adat Nagari (KAN), dan masyarakat yang melakukan perkawinan antar etnis, serta masyarakat yang tidak melakukan perkawinan antar etnis.

\section{HASIL DAN PEMBAHASAN}

\section{Dampak Perkawinan Adat antara Etnis Mandailing Dengan Minangkabau terhadap Sistem Kekerabatan Anak}

Berdasarkan temuan dilapangan, jumlah masyarakat yang melakukan perkawinan campur adat di Nagari Lansek Kandok tahun 2016 adalah sebanyak 146 KK. Perkawinan antar etnis terjadi antara etnis Mandailing dengan etnis Minangkabau. Tiap-tiap adat mempunyai tata aturan hukum yang berbeda sehingga perkawinan ini rentan permasalahan terkait dengan sistem kekerabatan dan hak waris. Sistem kekerabatan Mandailing memakai sistem kekerabatan yang mengambil garis keturunan dari pihak laki-laki. Sedangkan istri akan menjadi warga masyarakat dari pihak laki-laki atau suaminya demikian juga terhadap anak-anak yang akan lahir akan mengambil garis keturunan ayahnya atau mengikuti kekerabatan bapaknya. Siahaan (1983:14) mengatakan garis keturunan ibu/perempuan tidak diperhitungkan karena apabila seorang perempuan sudah berumah tangga maka si perempuan itu telah masuk ke marga pihak suaminya.

Sistem

kekerabatan Minangkabau memakai sistem kekerabatan yang mengambil garis keturunan perempuan. Oleh sebab itu setelah perkawinan berlangsung istri akan tetap tinggal dirumah orang tuanya. Anak-anak yang lahir akan mengambil sistem kekerabatan yang mengambil garis keturunan ibunya. Akmal (2018:10) mengatakan hubungan kekerabatan menurut garis ibu (matrilineal) seperti adanya keluarga, gabungan paruik dalam satu kaum, dan gabungan kaum dalam satu suku yang dipimpin oleh seorang penghulu adat. Fungsinya adalah menentukan bentuk hubungan, batas wewenang setiap struktur dalam pranata sosial yang ada dalam masyarakat hukum adat. Sukmasari (2009:98) mengatakan sistem matrilineal menempatkan pria Minangkabau pada posisi yang sulit dan rumit. Sebab bila mereka ingin menikahi wanita diluar suku Minangkabau maka resikonya adalah garis keturunannya akan terputus dari etnis Minangkabau.

Berdasarkan wawancara dan pengamatan peneliti, dampak perkawinan antar suami etnis Mandailing dengan istri etnis Minangkabau terhadap anak yaitu anak akan memperoleh marga dan suku dari orang tuanya. Artinya anak dianggap baik didalam kelurga ayahnya maupun ibunya ini 
disebabkan oleh garis keturunan kedua orang tunya bisa diturunkan. Dalam adat Mandailing garis keturunan diambil dari pihak ayah dan diturunkan kepada anak sedangkan didalam adat Minangkabau garis keturunan di ambil dari pihak ibu dan diturunkan kepada anak. Oleh sebab itu anak mendapat marga dari ayahnya dan mendapatkan suku dari ibunya. Beberapa pertanyaan penelitian terkait tentang perkawinan campur memiliki jawaban yang diantaranya oleh ibuk Marni. Dimana didalam kelurga beliau sistem kekerabatan yang paling menonjol adalah sistem kekerabatan ayah namun anak juga masih dianggap didalam pihak keluarga ibu. Menurut pengamatan peneliti anakanak lebih menonjolkan sistem kekerabatan ayah namun tidak ada pemaksaan untuk anak untuk memilih atau menonjolkan sistem kekerabatan Mandailing atau Minangkabau.

Dengan sistem kekerabatan suami etnis Minangkabau dengan istri etnis Mandailing, dampaknya terhadap anak yaitu anak tidak mendapatkan marga dan suku dari orang tuanya sebab garis keturunan kedua orang tuanya terputus. Akmal (2019:111) mengatakan hukum adat Minangkabau minimal harus memenuhi persyaratan fisik salah satunya basuku banagari, artinya agar mempelai dianggap sebagai masyarakat Minangkabau harus mempunyai suku. Oleh sebab itu sebelum kawin suami atau istri akan diberi marga atau suku sesuai kesepakatan suami istri dengan tujuan agar garis keturunan tetap bisa diturunkan kepada anak dan perkawinan yang dilakukan secara adat jujur maka suami akan bertanggung-jawab terhadap anak dan istrinya. Selain itu, pemberian marga juga agar tidak memutuskan hubungan kekelurgaan terhadap kedua orang tua kandungnya dan kekerabatan asal. Dengan begitu dia masih tetap sebagai mamak dalam kekerabatannya dan masih dapat mewariskan gelar pusaka. Dalam keluarga ini anak-anak dari perkawinan suami etnis Minangkabau dengan istri etnis Mandailing diberi kesempatan sendiri untuk memilih kekerabatan ayahnya atau ibunya yang akan dipilih dan akan dipakai dalam kehidupan sehari-harinya dan diputuskan melalui kesepakatan antara kedua orang tua dan kekerabatan ayahnya.

\section{Dampak Perkawinan Adat antar Etnis Mandailing dengan Minangkabau terhadap Hak Waris Anak}

$\begin{array}{rrr}\begin{array}{r}\text { Sistem } \\ \text { Mandailing } \\ \text { Menurut }\end{array} & \begin{array}{r}\text { dalam } \\ \text { Sugiman }\end{array}\end{array}$ (2001:67) mengatakan hukum waris adat Batak di turunankan kepada lakilaki dari pewaris pada azasnya yang mewarisi. Kalau pewaris tidak mempunyai turunan anak laki-laki, maka harta bendanya diwariskan kepada ahli waris lainnya yang terdiri dari anak laki-laki yang satu marga dan satu keturunan dengan pewaris. 
Hukum waris Batak pada asasnya merupakan perpindahan atau merupakan peralihan harta benda pewaris kepada ahli waris yang hanya terdiri dari laki-laki saja dengan singkat menurut hukum warisan adat Batak. Didalam etnis Minangkabau, harta warisan terbagi dua yaitu pusako tinggi dan pusako rendah. Pembagian warisan diberikan kepada ahli waris penerima warisan itu menurut adat. Menurut Perpatih Nan Tuo (2002:69) pusako tinggi yaitu harta kaum yang diterima secara terun temurun dari ninik ke mamak, dari mamak kepada kemenakan. Harta kaum tidak dapat diturunkan kepada anak menurut hukum syarak, karena bukan milik. Pusako rendah berasal dari harta pencarian suami istri. Baginya berlaku warisan kepada anak-anak menurut ketentuan hukum Faraidhm yakni hukum agama Islam. Kongres Tungku Sajarangan yang dilangsungkan pada tahun 1952, sepakat menyatakan harta pusaka tinggi jatuh kepada kemenakan dan harta pencarian diwariskan menurut hukum Faraidh.

Berdasarkan temuan yang peneliti dapat dilapangan bahwa perkawinan antar etnis adat suami etnis Mandailing dengan istri etnis Minangkabau dalam pembagian hak waris anak laki-laki dan anak perempuan sama-sama sebagai ahli waris disebabkan garis keturunan ayah dan ibunya bisa diteruskan oleh anaknya. Anak perempuan mendapat bagian dari ibunya dan anak laki-laki mendapat hak warisan dari ayahnya.
Namun untuk pembagian hak waris harta pencarian itu diturunkan oleh anak laki-laki sebab di dalam keluarga perkawinan antar etnis adat sistem yang lebih menenjol adalah sistem kekerabatan ayah.

Harta pencarian dan harta bawaan dalam perkawinan campur adat di Nagari Lansek Kadok dimiliki dan dikuasai oleh suami sebagai kepala kelurga dan untuk masalah pemilikan tergantung dari kesepakatan kedua belah pihak apakah akan dimiliki secara bersamasama atau masing-masing. Namun dalam kelurga ini anak akan berpeluang untuk memperebutkan hak waris yaitu harta pencarian dari orang tuanya. Sebab dalam Mandailing harta pencarian hanya diwariskan kepada anak sedangkan didalam Minangkabau anak perempuan memperoleh harta pencarian separuh dari bagian anak laki-laki kecuali harta itu dihibahkan kepada anak perempuan. Bentuk pembagian harta warisan ini bisa dibagikan melalui kesepakan keluarga dan anak.

Dampak hak waris dalam perkawinan suami etnis Minangkabau dengan istri etnis Mandailing terhadap anak secara hukum adat yaitu anak tidak mendapatkan hak waris dari orang tuanya, disebabkan sistem kekerabatan garis keturunan kedua orang tunya tidak bisa diturunkan. Akmal (2019:14) mengatakan didalam adat nagari Minangkabau, apabila 
terjadi pelanggaran di bidang identitas dan pemenuhan hak-hak tradisional maka tidak mendapatkan ulayat. Terkait dengan harta bawaan si suami dengan istri ada dua cara penentuannya. Pertama, harta perkawinan maupun harta bawaan si suami dan istri dimiliki dan dikuasai oleh suami sebagai kepala rumah tangga. Kedua, tergantung dari kesepakatan kedua belah pihak apakah akan dimiliki secara bersamasama atau masing-masing.

Secara adat harta warisan dari kelurga ini akan turun kepada kemenakan perempuan suami dan kepada kemenakan laki-laki istri, anak akan mendapatkan hak waris apabila dihibahkan kepada anak. Tetapi menurut pengamatan peneliti sistem pewarisan telah terjadi pergeseran. Sistem pewarisan yang semula memakai sistem pewarisan patrilineal berubah menjadi sistem parental sehingga anak laki-laki dan anak perempuan mendapat warisan. Ada juga yang menggunakan hak waris islam, pembagian hak waris ini dilakukan dengan cara musyawah oleh orang tunya dan kekerabatan ayahnya.

\section{SIMPULAN}

Berdasarkan temuan dan pembahasan hasil penelitian dapat ditarik beberapa kesimpulan yaitu sistem kekerabatan pada perkawinan antar etnis dalam masyarakat yang menganut patrilineal pada umumnya telah terjadi perubahan dimana masyarakat yang melakukan perkawinan antar etnis menggunakan sistem kekerabatan menurut hukum islam. Sementara pada masyarakat yang menganut matrilineal telah terjadi pergeseran seperti halnya sistem patrilineal menggunakan sistem kekerabatan hukum islam namun suku masih diambil dari pihak ibu. Dengan adanya perkawinan antar etnis menyebabkan sistem kekerabatan kepada anak-anak sebagai keturunan dari orang tuanya yang tidak satu suku baik anak lakilaki maupun anak perempuan sama derajatnya atau sama-sama menonjol dalam kelurga orang tuanya.

Dari aspek pembagian harta warisan pada perkawinan antar etnis dalam masyarakat yang menganut patrilineal telah mengalami perubahan. Pewarisan hukum waris yang dijalankan pada masyarakat yang melakukan perkawinan antar etnis pada umumnya menggunakan sistem pewaris berdasarkan hukum islam dengan sistem individual bilateral. Sedangkan dalam pembagian harta warisan pada perkawinan antar etnis yang menganut sistem kekerabatan matrilineal, pewarisan tidak dilakukan melalui sistem kekerabatan dari mana ia berasal tetapi dilakukan sesuai dengan kesepakatan dari ahli waris seperti halnya sistem patrilineal yang mengalami pergeseran pembagian yang dilakukan menurut kebiasaan setempat atas kesepakatan. Adanya perkawinan antar etnis meyebabkan pewarisan kepada anak-anak sebagai keturunan dari pihak orang tua yang tidak satu suku baik anak laki-laki dan anak perempuan sama-sama dapat menjadi ahli waris dan berhak atas warisan dari orang tuanya. Bersadarkan kesimpulan diatas maka 
peneliti ingin menyampaikan yaitu bagi masyarakat yang melakukan perkawinan campur yang menggunakan ketentuan perkawinan secara nasional agar tidak membedakan antara anak laki-laki dan perempuan khususnya dalam hal pewarisan sebab anak laki-laki dan perempuan dimata Tuhan dan UUD adalah sama.

\section{DAFTAR PUSTAKA}

Febrianto, Adri. (2011). “Orang Minangkabau dan Batak Mandailing di Nagari Buayan". Jurnal Ilmu Sosial. Vol.10. No.1.

Akmal, A. (2008). "Perlindungan Hak Masyarakat Hukum Adat di Sumatera Barat. Jurnal Demokrasi", Vol.7. No.1.

Akmal, A. 2019. Model Pemberdayaan Masyarakat Hukum Adat Di Sumatara Barat. Jawa Tengah: CV.Pena Persada Redaksi

Amir. 2011. Adat Minangkabau pola dan tujuan hidup. Jakarta: Citra Harta Prima.

Setiady, Tolip. 2009. Hukum adat Indonesia. Jakarta: Rineka Cipta.

Siahaan. 1983. Ciri-ciri khas adat daerah sumatra barat. Medan: kebudayaan Daerah.

Sugiman. 2001. Adat dan upacara perkawinan daerah. Sumatra Barat: Kebudayaan Daerah.

Sukmasari, Fiony. 2009. Traditional wedding of minangkabau. Jakarta: Citra Harta Prima.

Tuo Nan, Perpatih. 2002. Adat basandi syarak, syarak basandi kitabullah pedoman hidup banagari. Padang: Surya Citra Offset Padang

Raudy, Tagor. (2004). "Praktek Perkawinan Jujur Antara
Volume 2 No. 52019

Masyarakat Batak Dengan

Masyarakat Minangkabau Di

Kecamatan Panti Kabupaten

Pasaman". Jurnal Ilmiah Mahasiswa Pendidikan Kewarganegaraan. Vol.1. No.3.

Fitriatmuko, Riyan. (2017). "Praktik perkawinan campur antara masyrakat adat di Kota Batam dan akibat hukumannya (studi pada perkawinan campur antara pria Batak dengan wanita Minangkabau di Sungai Panas Kota Batam)". Jurnal ilmiah ilmu hukum. Vol.6. No.2.

Sundari, Ulfa. 2013. "Sitem perkawinan dalam perkawinan antara suku Batak dan suku Minangkabau (Studi di Kota Medan)": Fakultas Ilmu Sosial. Universitas Sumatera Utara.

Simanjuntak, Sumiati. (2018). "Adat istiadat dalam keluarga amalgamasi Batak dan Minangkabau di Kecamatan Tampan dan Payung sekaki Kota Pekanbaru". Jurnal so siologi. Vol.5, No.1 